natural rubber at low temperatures, but it may be produced almost instantaneously by stretching at normal temperatures. Crystallization profoundly affects the physical properties of rubber, and its study has had an important bearing on the elucidation of its molecular structure.

\section{White Rainbow at Malvern}

AN account of a white rainbow has been received from Mr. R. H. Stevens of "Rockland", Cowleigh Road, Malvern. The bow was seen at about 10.30 a.m. on November 8 after a short snowstorm, but no snow could be seen to be falling at the time of the observation. The white rainbow, also known as the 'fogbow' or 'Ulloas Ring', is a rare phenomenon due, as in the case of the ordinary coloured rainbow, to refraction and reflexion of sunlight in falling drops of rain, but the raindrops composing the cloud must be very small- $0.1 \mathrm{~mm}$. or less in diameter. When this is the case, the first maxima of intensity for the different colours of the spectrum are spread out over a wider angle than with the larger drops, and are nearly coincident, the result being approximately to restore the original colour of the sunlight. The bow is only bright enough to be visible in exceptionally favourable circumstances and when the observer is near the cloud which contains the small drops. In this instance the previous occurrence of snow must be assumed to have been fortuitous, the snow probably having originated from clouds at a higher level than that of the cloud which carried the water drops.

\section{Recent Earthquakes}

DurING August 1944, five strong earthquakes were registered by the seismographs at the Dominion Observatory, Wellington, New Zealand. The first of these, on August 8, from an estimated epicentral distance from Wellington of a little more than $48^{\circ}$, had a depth of focus near $80 \mathrm{~km}$. Those of August 15, 25 and 30 all had a depth of focus near $100 \mathrm{~km}$. In addition, thirteen earthquakes and tremors originated in or near New Zealand during the month and were felt by people in the Dominion.' The strongest of these, on August 16, was felt with intensity 5 on the modified Mercalli scale in the region of Kahurangi Point. Others with intensity 4 were in the southern part of North Island on August 14; on the west coast of the North Island-WanganuiWellington, on August 17; and in the Wairarapa and north Wellington region on August 26.

The United States Coast and Geodetic Survey in co-operation with Science Service and the Jesuit Seismological Association has determined the provisional epicentres of three earthquakes on September 23, October 2 and 6 . The earthquake of September 23 , which took place about $12 \mathrm{~h}$. $13 \cdot 3 \mathrm{~m}$. G.M.T., had its epicentre near lat. $53 \cdot 5^{\circ} \mathrm{N}$., long. $160 \cdot 7^{\circ} \mathrm{E}$., which is in the Kamchatka Peninsula. It was reported as registered by fourteen seismological stations. The earthquake of October 2 at $17 \mathrm{~h} .21 \cdot 9 \mathrm{~m}$. G.м.т. had its epicentre near lat. $14 \cdot 5^{\circ} \mathrm{N}$., long. $90 \cdot 1^{\circ} \mathrm{W}$., which is in Guatemala. The shock of October 6 at $2 \mathrm{~h} .34 \cdot 7 \mathrm{~m}$. G.M.T. occurred at lat. $39^{\circ}$ N., long. $27^{\circ} \mathrm{E}$., which is in Turkey. The earthquakes of September 23 and October 6 were registered by Mr. E. W. Pollard at his observatory at Binstead, Isle of Wight. Between August 2 and October 31, Mr. Pollard's home-made apparatus registered twenty-three earthquakes and tremors, mostly from large distances.
Recordings for the period October, November and December 1943 have just been received from Suva, Fiji. Altogether thirty-seven earthquakes were registered during the period. These registrations are most useful when taken in conjunction with those of New Zealand, Australia and America.

\section{Scientific Literature for Liberated Europe}

An appeal, signed by Sir William Beveridge, Prof. P. M. S. Blackett, Mr. E. Carter, Mr. J. G. Crowther, Dr. C. D. Darlington and Sir Richard Gregory, has been issued for literature dealing with advances made in Allied Countries during the War for dispatch to liberated Europe. In particular, French men of science need this material as quickly as possible. In Paris, there is gas and electricity for only one or two hours in the evenings, so that experimental work is scarcely possible. All material sent to France would be fully used. Literature would go to the Centre National de Recherche Scientifique in Paris, which is in touch with the whole body of French scientific workers. Single copies would be microfilmed, and films and abstracts distributed. Thus the greatest possible use could be made immediately of any periodicals that can be sent to them. Sets of journals and single copies should be sent to the Association of Scientific Workers, Hanover House, 73 High Holborn, London, W.C.I.

\section{Conference on the Place of Science in Industry}

THE Division for Social and International Relations of Science of the British Association is arranging a conference on "The Place of Science in Industry" to be held on January 12 and 13 at the Royal Institution, Albemarle Street, London, W.1. The conference will be opened by Sir Richard Gregory, president of the Association, and there will be four sessions, at which the chair will be taken respectively by $\mathrm{Mr}$. Ernest Bevin, Lord MeGowan, Sir John Greenly and Lord Woolton. The subjects of the sessions will be : what industry owes to science, fundamental research in relation to industry, industrial research and development, and the future-what science might accomplish. A limited number of tickets will be available for the public other than members of the Association, and may be applied for at the office of the British Association, Burlington House, London, W.1.

\section{Announcements}

Dr. SrDney E. Smith, who recently resigned from the presidency of the University of Manitoba to take up the appointment of principal of University College, Toronto, and executive assistant to the president of the University of Toronto, the Rev. H. J. Cody, will succeed Dr. Cody as president on July 1, 1945 .

The Langley Memorial Prize, value $£ 21$, is open to competition among officers of the Colonial Medical Service who are serving, or who have served, in West Africa. The prize will be awarded for a paper on (a) tropical medicine or surgery ; (b) tropical hygiene and sanitation; or (c) tropical entomology and parasitology. Papers, which may consist of either published or unpublished work, should be delivered to the Secretary, London School of Hygiene and Tropical Medicine, Keppel Street, Gower Street, London, W.C.1, not later than October 1, 1945. 